\title{
Analysis on National Environment of Green Building Assessment Scheme in America and China
}

\author{
Author: Guo An Wei, Jun Ze Wang \\ Engineering Management Department of Henan Technical College of Construction, Gongye Rd, Erqi District, Zhengzhou, Henan, China
}

\begin{abstract}
This paper briefly analyses the differentiation of the Green Building Assessment Scheme between America and China from the national environment angle to demonstrate the importance of government guidance in the development of green buildings. The establishment of LEED (Leadership in Energy \& Environmental Design) mainly complies with the regulation of market mechanisms. On the contrary, China's Green Building Assessment Scheme "GB/T 50738" cannot entirely rely on the market mechanism due to the national environment. In order to improve the GB/T 50738 to meet Green Building development in China, several suggestions have been proposed in the paper to increase the efficiency and practicality of GB/T 50738 implementations.
\end{abstract}

\section{Introduction}

On November 13, 2017, the Global Carbon Project released a research report of "2017 Global Carbon Budget", which states global carbon dioxide emissions have grown remarkably by $2 \%$ in 2017 compared to the previous threeyears' zero growth. China's carbon emissions take possession of $28 \%$ of the total carbon emissions with the highest proportion as well as the fastest growth in the world, which leads to serious issues on sustainable growth in Chinese society.

The report of the Chinese 19th Congress pointed out, although China's ecological establishment has achieved greater outcomes during the 12th Five-Year Plan period than before, many issues are existing still such as construction wastes reached 300 million tonnes annually [1]. Therefore, improving the legislative systems and policies for green buildings is essential to China's sustainable development.

As a result, the Chinese government even paid more attention to green building assessment schemes globally to measure the energy efficiency of green buildings such as Leadership in Energy and Environmental Design (LEED) brought by the USA and Building Research Establishment Environmental Assessment Method (BREEAM) come up by Britain.

There are plenty of literatures analysed the comparison of green building assessment scheme, according to the geographical division, for example, comparisons among China and the United Kingdom [2], United States [3], Japan [4], the Netherlands [5]. All of them compared the method of energy-saving [9], water-saving indicators [10], and rain- flood control indicators [10] in the green building assessment scheme [6-8]. However, only a few literatures analyse the difference in green building assessment schemes among China and other countries from the perspective of the national environment.

At present, the most widely used green building assessment schemes in the world are the LEED framework of the United States. Thus, China's "Green Building Assessment Scheme" BG/T 50738 learned from the U.S. LEED framework when it was originally compiled. The contents of the two schemes have many similarities. Since the political environment is quite different, socialism and capitalism, it is impossible to entirely imitate U.S. LEED for China's situation. Therefore, this paper would aim to compare the national environment between the U.S. and China to discover and propose better policies for China to implement the green building assessment scheme effectively.

\section{The U.S. and China Green Building Assessment Scheme}

\subsection{The U.S. LEED}

As early as 1994, the US Green Building Council (USGBC) developed the Leadership in Energy \& Environmental Design (LEED), which is to assess various types of buildings, which includes not only building materials used in the construction stage but also the energy consumption during the operation stage. Moreover, the site selection and indoor air quality during the using stage are evaluated. Since 1998, the LEED 1.0 has evolved to more accurate representation. 
Later on, LEED v2/v2.2 in 2005, LEED v3 in 2009 and LEED v4 in 2013 have been improved to a comprehensive system containing all aspects of the construction process, see Table 1). And the evaluation objects have gradually.

Table 1 Version upgrading

\begin{tabular}{|c|c|}
\hline Version & Years \\
\hline LEED v1 & 1998 \\
\hline LEED v2/2.2 & 2005 \\
\hline LEED v3 & 2009 \\
\hline LEED v4 & 2013 \\
\hline
\end{tabular}

increased to form a mature system framework in the latest version LEED v4 which contains several aspects, Green Building Design \& Construction, Green interior Design \& Construction, Green Building Operation \&maintenance, Green Neighborhood Development, and Green Home Design \& Construction see Table 2).

LEED v 4 Content

Table 2

\begin{tabular}{|c|c|}
\hline Categories & Contents \\
\hline $\begin{array}{l}\text { LEED Green } \\
\text { Building Design \& } \\
\text { Construction }\end{array}$ & $\begin{array}{c}\text { LEED for New } \\
\text { Construction, Core \& } \\
\text { Shell, School, Retail: New } \\
\text { Construction and Major } \\
\text { Renovations, Healthcare }\end{array}$ \\
\hline $\begin{array}{l}\text { LEED Green } \\
\text { Interior Design \& } \\
\text { Construction }\end{array}$ & $\begin{array}{l}\text { LEED for Commercial } \\
\text { Interiors, Retail: } \\
\text { Commercial Interiors }\end{array}$ \\
\hline $\begin{array}{l}\text { LEED Green } \\
\text { building Operations } \\
\text { \& maintenance }\end{array}$ & $\begin{array}{c}\text { LEED for Existing } \\
\text { Buildings: Operations } \\
\text { \&Maintenance }\end{array}$ \\
\hline $\begin{array}{l}\text { LEED Green } \\
\text { Neighborhood } \\
\text { Development }\end{array}$ & $\begin{array}{l}\text { LEED for } \\
\text { Neighborhood } \\
\text { Development }\end{array}$ \\
\hline $\begin{array}{l}\text { LEED Green Home } \\
\text { Design and } \\
\text { Construction }\end{array}$ & LEED for Homes \\
\hline
\end{tabular}

\subsection{China's GB/T 50738}

Compared with the LEED, China's GB/T 50738 started late. The promulgation of the 2006 Green Building Evaluation Standards (GB/T 50378-2006) represents that the first green building assessment scheme guideline has established in China. With the high-speed development of green buildings in the practice, the shortfalls of the 2006 version "GB/T 50378-2006" have become obvious right after a few years' implementations, which triggered a high requirement of the industry as well as the government for revision and improvement. The new version of GB/T 50378 - 2014 was enforced to revise and update the previous version. Afterward, the latest version "GB/T 50738-2019" was issued to meet the requirements of green building development on March, 13th, 2019. Based on the core concept of "four sections and one environmental protection", adjustments were made in terms of the methods, assessment indicators and assessment stages (see table 3) to make them closer to practice. 


\section{Comparison between current and previous (GB/T 50738) in China}

Table 3

\begin{tabular}{|c|c|c|}
\hline 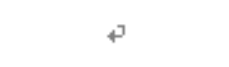 & 【GB/T50738-2006】 & 【GB/T 50738-2019】 \\
\hline $\begin{array}{l}\text { Applicable } \\
\text { types }\end{array}$ & $\begin{array}{l}\text { Residential building, office building, commercial building, } \\
\text { infrastructure }\end{array}$ & All types of building \\
\hline Stages & One year after operation of building: & Design stage, operation stage \\
\hline Contents & $\begin{array}{l}\text { (1) land saving and extemal environment; (2) energy } \\
\text { savingand usage; (3) water saving and usage; (4) sources } \\
\text { and material usage; (5) interior environment quality ; (6) } \\
\text { operation management }\end{array}$ & $\begin{array}{l}\text { Based on the previous version, } \\
\text { adding two more items: ( } 7 \text { ) } \\
\text { construction management; ( } 8 \text { ) } \\
\text { innovation increase }\end{array}$ \\
\hline Methods & Based on compliance project to classify & Quantitative assessment \\
\hline
\end{tabular}

\section{China-US political environment}

\subsection{LEED in US political environment}

The development of the LEED scheme is proposed by the non-profit, U.S. Green Building Council (USGBC) in the first place, which includes a set of rating schemes for the design, construction, operation, and maintenance. Its membership contains construction companies, educational institutions, government departments, etc. These construction companies can provide a significant platform to propagate the newest architectural concept and technology to the entire construction filed. The establishment of the LEED system takes several requirements into account from the government, company, customers, and related organizations in the US which resulted in a remarkable outcome after the implementation through the driving force of the market mechanism.

At the beginning of the LEED establishment, the US government's policy provided a friendly environment to enforce the LEED. Firstly, the U.S. government enforced government buildings and government-invested buildings for energy-saving purposes and applied the LEED test. Later on, in 2003, the US State Department requested that the US embassies' building should also conform to LEED worldwide. In 2005, the US Congress enforced the Energy Policy, which raised building energy efficiency to an unprecedented level. It requires not only the government buildings to have water-save, energy-save, limitation of carbon dioxide emissions, but also encourages construction company and organisation to participate and apply LEED to acquire the benefits of tax deduction. A range of measures effectively stimulated the market acceptance of the Green building as well as LEED. In 2009, the US government required government buildings to be gradually reconstructed to sustainable buildings and achieve the final goal of zero energy consumption. In the same year, US President Barack Obama signed the "Economic Stimulus Act", which is a crucial method to evolve the sustainable system as well as stimulate the economy, the green building industry received a large amount of capital investment and growing rapidly.

The United States not only promotes green buildings at the national level but also enforced at the state level by providing a series of incentive policies. Firstly, the construction Regulations Committee of local councils responsible for the development of regional buildingstandard adds up sustainable provisions to coordinate with the development of green buildings. Secondly, some local councils will simplify the procedure of application and review of project development. Thirdly, the floor area ratio of private green building projects would have fewer requirements than traditional building projects. Finally, advanced technologies are supplied. In terms of financial incentives, not only would the application and approval fees be decreased, but also a tax deduction allowance is provided.

\subsection{GB/T 50738-2019 in the Chinese political environment}

In order to standardize the production of Olympic buildings perfectly, several domestic companies and departments coordinate with US Natural Resources Defense Council and the Japan Building Comprehensive Environmental Assessment Research Committee to establish the "greening" standards for Olympic buildings from 2003 to 2005. This standard provides related references and experience for GB/T 50378-2019 in China. Furthermore, the National People's Congress and the State Department have successively issued a series of legislation and policies to 
guarantee effective implementation of GB/T 50378-2019 during the process of China's green building development.

In terms of legislation, in January 1998, the " People's Republic of China Energy Conservation Law" was enforced, which clarified the government's duty for building energy conservation, supervision, and determined the legal liabilities of the participants in the construction industry; in March 1998, the "People's Republic of China construction law" was enforced. This Law has become the basic legal foundation for China's engineering construction management. In terms of regulations, "Energy Conservation Regulations for Civil Building" and Energy Conservation Regulations for the public sector were enforced in October 2008 respectively.

Provincial governments also actively cooperate with central government policies to issue regional instructions on GB/T 50378-2019 implementation. Since different provinces' modernisation are not at the same level, the implementation of GB/T 50378-2019 can not be unified nationwide still. Such as Shanghai, Guangdong is leading the way of implementation GB/T 50378-2019.

In the contrast with US incentive policies, the Chinese government also provides a series of incentive policies which can be divided into land awards (including land transfer land planning, etc.), financial awards (including financial subsidies, tax benefits, etc.), and administrative policies (including simplifying approval procedures) Among them, the most widely used is financial awards, which can quickly encourage the construction company and industry to achieve the requirements.

Due to the particularity of China's land ownership, many provinces set green buildings as a precondition for the auction of land. This compulsory regulation can improve the competition among companies in the matured region on the greening building. However, it is not an appropriate way for these developing regions, since local construction enterprises would be defeated.

Financial policy refers to the floating interest rate of green construction loans from financial institutions, including construction loans and home loans. In the long term, this incentive policy has a significant effect on real estate developers since they can offset the incremental cost of green building construction through an appropriate plan.

\section{Inspiration to China}

The U.S. LEED was developed and released by the nonprofit U.S. Green Building Council to improve the environmental responsibility for the construction industry. In comparison, China's "Green Building assessment scheme" is officially issued and enforced, which is a deeply compulsory system Implemented from the top down. However, from the perspective of the market integration of the green building assessment, there is still a big gap between the two. During the next "Five-Year Plan" period, the implementation of the green building assessment scheme needs to upgrade to meet the construction industry changes.
(1) Regional collaborative work

Since China has vast territories and regional differences, different regions must have individual ideas to adapt to local practices and developing the status quo. The implementation of GB/T 50738-2019 is at different stages in different regions, even though the GB/T 50738-2019 has a hierarchical design to require the entire construction industry to comply. Besides, due to the assessment system of GDP growth, regional protection widely exists in local government which would prioritise to choose these local constructions with less advanced techniques even. This consequence would block the most advanced technology widely applied in China. Therefore, the regional government should set up a series of policies to encourage local companies to improve instead of staying in the safe zone. For example, local companies are permitted to set their technical office in these leading companies which win the bidding of local projects to learn the advanced techniques. Furthermore, the regional government should equally treat local and other companies to stimulate local companies rising their competitive capabilities.

(2) Financial subsidy and allowances

Based on the "report of development mode and investment forecast on china green building industry (20192024)" [11], the local government issued a series of incentive policies and regulations on green buildings, which contains binding conditions in the entire lifecycle of projects since 2013.

Even though these current subsidies can encourage construction companies and real estate developers to apply GB/T 50738-2019, home buyers barely have any subsidy or benefits supplied by the government when they are purchasing green-building homes. Therefore, the government should consider this method to encourage home buyers to choose these green buildings which can stimulate real estate developers to be more competitive for satisfying the customer's needs instead of transfer funds to them straight. See table 4).

(3) GB/T 50738-2019 updating period

According to GB/T 50738-2014\&2019, upgrading of GB/T 50738 is usually every 5-years round. However, this rigorous requirement cannot satisfy, even obstruct the fast development of the green building field. For example, based on GB/T 50738-2019, safety and durability in chapter 4 applies mostly brand-new standards to meet the market requirements. On the contrary, health and comfort in chapter 5 still maintains a large proportion of the old standard since there is less updating in those fields. Therefore, the government should apply a flexible upgrading period instead of a set period of upgrading on GB/T 50738 to comply with the development of the green building.

(4) Establishing feedback channel through database collection

With the development of techniques, implanting chips into modern buildings has been applied in many industries such as the high-speed train in China. These implanted chips within the railway system to monitor and discover the 
deviation even damage after long-term usage. Therefore, a green building should also apply this an advanced technique to detect the defect from either construction material or design.

Table 4 Financial subsidy and allowance

\begin{tabular}{|c|l|l|}
\hline Region & Policy name & Subsidy standards \\
\hline BEIJING & $\begin{array}{l}\text { Beijing Green Building Development and Promotion in } \\
\text { Ecological Demonstration Zone Construction Financial } \\
\text { Incentive Funds Interim Regulation }\end{array}$ & $\begin{array}{l}\text { 2-star projects: } 22.5 \mathrm{yuan} / \mathrm{m} 2 \\
\text { 3-star projects: } 40 \text { yuan } / \mathrm{m} 2\end{array}$ \\
\hline TIANJING & $\begin{array}{l}\text { Tianjin Green Building Pilot Construction Project } \\
\text { Management Regulation }\end{array}$ & $\begin{array}{l}\text { Subsidy limitation: } 50 \mathrm{k} \text { Transferred by } \\
\text { 2 times: } \\
\text { 30k at the beginning, 20k after project } \\
\text { completion acceptance }\end{array}$ \\
\hline SHANGHAI & $\begin{array}{l}\text { Shanghai Building Energy Saving and Green Building } \\
\text { Demonstration projects Support Regulation }\end{array}$ & $\begin{array}{l}\text { 2-star projects:50 yuan } / \mathrm{m} 2 \\
\text { 3-star projects: } 100 \text { yuan } / \mathrm{m} 2\end{array}$ \\
\hline CHONGQING & $\begin{array}{l}\text { Chongqing Green Building Project Subsidy Fund } \\
\text { Management Regulation }\end{array}$ & $\begin{array}{l}\text { Gold level: } 25 \text { yuan } / \mathrm{m} 2 \\
\text { Platinum level: } 40 \text { yuan } / \mathrm{m} 2\end{array}$ \\
\hline JILIN & $\begin{array}{l}\text { Jilin Green Building, Energy Saving Award Fund } \\
\text { Management Regulation }\end{array}$ & $\begin{array}{l}\text { 2-star projects: } 15 \mathrm{yuan} / \mathrm{m} 2 \\
\text { 3-star projects: } 25 \text { yuan } / \mathrm{m} 2\end{array}$ \\
\hline SHANDONG & $\begin{array}{l}\text { Shandong Building Energy Saving and Green Building } \\
\text { Development of Special Fund Management Regulation }\end{array}$ & $\begin{array}{l}\text { 1-star projects: } 15 \text { yuan } / \mathrm{m} 2 \\
\text { 2-star projects:30 yuan } / \mathrm{m} 2 \\
\text { 3-star projects: } 50 \text { yuan } / \mathrm{m} 2 \\
\text { 5 million top limit }\end{array}$ \\
\hline
\end{tabular}

\section{Conclusion}

In the context of global resource shortages and ecological environmental deterioration, the development of ecological and sustainable green buildings are the essential direction in the transformation of the construction industry. Through a comparison between U.S. LEED and GB/T 50738-2019, China's "GB/T 50738-2019" is mainly established by the central government, which can not fully conform with the market mechanisms. Due to different political environments, the Chinese government should adjust current circumstances to conform to the development rules of green building.

\section{Acknowledgement}

Fund Project: 2019 Henan Province Science and Technology Department Key Research and Special Projects 2019 Henan Province Housing and Urban-rural Construction Department Science and Construction Plan Projects

\section{Reference}

1. Q.Shi, X.D.Lai, X.Xie, J.Zuo, Elsevier, Renewable and Sustainable Energy Reviews, 68, 262-271(2017)

2. Y. Gan, R.Gu, CAJEPH. Analysis on The Comparison
Among BREEAM, LEED and GBL, 120-122(2016.05)

3. T.Zhou, Tu, U.S. LEED-NC Green Building Assessment Scheme Indicator Research, (2014). Available at: http://cdmd.cnki.com.cn/Article/CDMD10056-1015041117.htm

4. C.S.Xie, T.J.Zhou, Sc, China and Japan Green Building Assessment Scheme comparason consideration. Sichuan construction. 31(01):6-9 (2011) Available at: http:/xueshu.baidu.com/usercenter/paper/show?paperi $\mathrm{d}=$ dbecf8fae6b29f0939c40dbe3b6291c0\&site=xueshu se

5. Q. Ye, Tu, Green Building PR-CN Comprehensive Performance Assessment Schemes and MethodsChina and Netherland Green Building Assessment Scheme Research, (2015) Available at: http://cdmd.cnki.com.cn/Article/CDMD-100561017130424.htm

6. G.M.Zhang, C.F.Shi, Ec, Domestic and Foreign Classic Green Building Assessment Scheme Comparison Research. 37(08):76-80 (2016) Available at: http://xueshu.baidu.com/usercenter/paper/show?paperi $\mathrm{d}=287$ ee317737cdcb9a170f539c2514bc0\&site=xueshu se

7. MY.M.Wan, R.Xu, T.Huang, Cs Green Building Assessment Scheme Comparison Research Between U.S. and China, 25(08):6-8 (2009) available at: http://xueshu.baidu.com/usercenter/paper/show?paperi $\mathrm{d}=\mathrm{ae} 2169 \mathrm{ea} 1383845 \mathrm{~b} 1 \mathrm{f132273866 \textrm {cd } 8 \mathrm { c } \& \text { site } = \mathrm { xueshu }}$ 
Se

8. J.P.Li, CES, LEED and Green Building Assessment Scheme Application, 38(05):64-66 (2010) Available at:

http://xueshu.baidu.com/usercenter/paper/show?paperi $\mathrm{d}=21 \mathrm{a} 919398660 \mathrm{ef} 2 \mathrm{a} 356514154 \mathrm{e} 4 \mathrm{e} 1810 \&$ site $=$ xuesh u_se

9. S.Y.Jia, M.H.Liu, Hvac, China's and Russia's Green Building Assessment Scheme Indicators Comparison, 46(02):8-11 (2016) Available at: http://xueshu.baidu.com/usercenter/paper/show?paperi $\mathrm{d}=80 \mathrm{e} 9 \mathrm{f} 3 \mathrm{c} 04 \mathrm{e} 4 \mathrm{~d} 7 \mathrm{e} 8 \mathrm{fbaf52} \mathrm{ac} 6668 \mathrm{ec} 48 \mathrm{~d} \&$ site=xueshu se

10. N.Wang, F.Wang, H.Z,Yang, Wss, Domestic and Foreign Green Building Assessment Scheme Analysis and Comparison in Water Saving, 45(11):208-212 (2009) Available at: http://xueshu.baidu.com/usercenter/paper/show?paperi $\mathrm{d}=81 \mathrm{e} 24 \mathrm{a} 869 \mathrm{a} 19 \mathrm{~b} 5629 \mathrm{f} 2 \mathrm{e} 37 \mathrm{f} 40 \mathrm{cb} 7359 \mathrm{c} \&$ site $=\mathrm{xueshu}$ se

11. X.B.Zhou, W.Che, Wss, GB/T 50738 and U.S. LEED Rain Flood Control, 45(03):120-124 (2009) Availble at:

http://xueshu.baidu.com/usercenter/paper/show?paperi $\mathrm{d}=\mathrm{b} 211 \mathrm{~b} 0 \mathrm{cb} 70 \mathrm{~b} 8 \mathrm{cdd} 12 \mathrm{f} 85 \mathrm{a} 007 \mathrm{bd} 69 \mathrm{~b} 539 \&$ site $=$ xuesh u_se\&hitarticle $=1$

12. Rqz, Report of Development Mode and Investment Forecast on China Green Building Industry (2019-2024) Available at https://bg.qianzhan.com/report/detail/f35efa6dbde2441 3.html 